\title{
Cholera Toxin B Subunit IgG Antibody Measurement
}

National Cancer Institute

\section{Source}

National Cancer Institute. Cholera Toxin B Subunit Ig G Antibody Measurement. NCI

Thesaurus. Code C116194.

The determination of the amount of cholera toxin B subunit IgG antibody present in a sample. 